\title{
Biocontrol of Botrytis cinerea by Ulocladium atrum in Different Production Systems of Cyclamen
}

\author{
J. Köhl, M. Gerlagh, and G. Grit, Plant Research International, P.O. Box 16, 6700 AA Wageningen, the \\ Netherlands
}

\begin{abstract}
Köhl, J., Gerlagh, M., and Grit, G. 2000. Biocontrol of Botrytis cinerea by Ulocladium atrum in different production systems of cyclamen. Plant Dis. 84:569-573.
\end{abstract}

Ten experiments in six different commercial greenhouses were conducted to study the effect of spraying conidial suspensions of the saprophytic fungus Ulocladium atrum $\left(1 \times 10^{6}\right.$ conidia per $\mathrm{ml}$ ) on infection of leaves and flower petioles of cyclamen by Botrytis cinerea (gray mold). The greenhouses represented the range of Dutch growing systems of cyclamen, differing considerably in the arrangement of plants, irrigation system, heating system, and material of pots. Applications of $U$. atrum suspensions were carried out at 4-week intervals only twice on young plants or were continued during the whole growing season until 4 weeks before plants were marketable. The antagonistic treatments were compared with untreated or water-treated controls and with fungicide applications as applied by growers. After applications of $U$. atrum at 4-weeks intervals, disease development was significantly reduced in experiments carried out in five different greenhouses. In no case did treatments with fungicides give better control than $U$. atrum treatments. Two applications of $U$. atrum resulted in sufficient control when plants were marketed within 60 days after the last application. In one greenhouse with an extremely high disease pressure, neither $U$. atrum nor fungicide applications controlled leaf rot. In additional experiments, the fate of $U$. atrum conidia on leaves of cyclamen grown in a system with topirrigation three times per week was studied during a period of 70 days. The number of conidia per square centimeter of green leaves declined by $50 \%$ during the first 10 days of the experiment but remained stable during the following 60 days. The percentage of germinated conidia on green leaves increased during the experiment to approximately $50 \%$. After additional incubation of leaf samples in moist chambers, more than $75 \%$ of the conidia had germinated, indicating that viable inoculum was present on leaves during the whole experiment. Artificial necrosis of leaves was induced by removing leaves from the plants. $U$. atrum colonized these leaves and competed successfully with $B$. cinerea on such leaves, even when they had been removed 70 days after the $U$. atrum application. Our results show that $U$. atrum has the potential to control leaf rot of cyclamen under a broad range of commercial growing conditions.

Botrytis cinerea causes leaf and fruit infections in numerous crops, including ornamentals. Its control in many ornamental crops depends on fungicides, but is often restricted because of the threat of development of fungicide resistance by the pathogen $(1,5,11)$, negative side effects of fungicides on plant growth, or visible residuals on plant surfaces (6). Alternatively to fungicides, antagonists can be utilized to achieve disease control. Biocontrol of $B$. cinerea by yeasts, bacteria, and filamentous fungi has been found in many crops (2).

The saprophytic fungus Ulocladium atrum has the potential to compete sapro-

Corresponding author: J. Köhl

E-mail: j.kohl@plant.wag-ur.nl

Funding for this study was provided by the Dutch Product Board for Horticulture and the Dutch Ministry of Agriculture, Nature Management and Fisheries.

Accepted for publication 10 January 2000.

Publication no. D-2000-0323-01R

(C) 2000 The American Phytopathological Society phytically with Botrytis spp. during the colonization of necrotic plant tissues (9). The inoculum potential of $B$. cinerea can be reduced by antagonistic interaction, leading to slower disease epidemics (8). Its high ecological competence makes $U$. atrum an attractive candidate for applications in fields and greenhouses $(3,10)$.

In cyclamen (Cyclamen persicum), naturally senesced leaves within the dense canopy play a crucial role in Botrytis epidemics. Since healthy leaves are normally resistant to conidial infections (12), $B$. cinerea depends on dead tissues for initial entry into the plant. Stimulated by this food base, the inoculum potential of the pathogen increases within the canopy of the single plant to such a level that healthy petioles and leaf blades can then be infected. The resulting gaps in the canopy reduce the ornamental value of the plant or lead to complete plant loss. Such losses are common, especially during the autumn production when environmental factors, such as high humidity, favor the disease.

In the cyclamen system, biocontrol of $B$. cinerea by $U$. atrum can be achieved by competitively excluding the pathogen from colonizing necrotic leaves present within the cyclamen canopy. This was recently shown by Köhl et al. (7). In their study, repeated applications of conidial suspensions of $U$. atrum controlled the disease as effectively as the grower's standard fungicide program. These experiments were carried out in a commercial greenhouse, where potted plants on tables were subirrigated by capillary matting. No top-irrigation was used.

However, cyclamen are produced in a variety of different growing systems, including those with top-irrigation. The purpose of our study was to investigate the potential of $U$. atrum for $B$. cinerea control in the broad range of commercial growing conditions used in cyclamen production in the Netherlands. It was not intended to compare the effect of different growing systems or cultivars on $B$. cinerea development. Experiments on antagonist survival in top-irrigated crops completed the studies on biocontrol in the various production systems. It was hypothesized that frequent top-irrigation may adversely affect antagonist efficacy since conidia may be washed off leaf surfaces. Furthermore, germinated conidia may become exhausted during frequent wet-dry periods, each possibly not long enough for conidia to germinate and colonize necrotic tissues.

\section{MATERIALS AND METHODS}

Inoculum production. Conidia of $U$. atrum isolate 385 , originating from a necrotic onion leaf tip (10), were produced on oat grains in autoclavable mushroom spawnbags (Type 3LS; Van Leer Ltd., Poole, Dorset, UK) and conidial suspensions containing $1 \times 10^{6}$ conidia per $\mathrm{ml}$ were prepared as described by Köhl et al. (7).

Plants. Cyclamen were seeded in trays with soil plugs and transferred at approximately 10 weeks to individual pots containing commercial potting soil.

Plants were 77 to 168 days old at the beginning of the experiments. At that stage, the oldest leaves were beginning to senesce, and plants were almost free from symptoms of $B$. cinerea. Only plants in greenhouse 3 had exceptionally high numbers of necrotic leaves (approximately 0.5 per plant), and symptoms of $B$. cinerea were found on approximately $25 \%$ of the plants. Varieties used in the individual experiments are shown in Table 1. 
Table 1. Effect of treatments of cyclamen with Ulocladium atrum or fungicides on Botrytis cinerea disease development (AUDPC) and disease manifestation at marketable age ${ }^{\circ}$

\begin{tabular}{|c|c|c|c|c|}
\hline \multirow[b]{2}{*}{ Treatment } & \multicolumn{2}{|c|}{ Disease devel. (AUDPC) } & \multicolumn{2}{|c|}{ Disease at marketing } \\
\hline & DIP $^{p}$ & DS $^{\mathbf{q}}$ & DI & DS \\
\hline \multicolumn{5}{|l|}{ Greenhouse 1 ; cv. Laser ${ }^{\mathrm{r}}$} \\
\hline Untreated & $\mathrm{nd}^{\mathrm{s}}$ & nd & $41 \mathrm{a}^{\mathrm{t}}$ & $0.8 \mathrm{a}$ \\
\hline Tween-water & nd & nd & $45 \mathrm{a}$ & $0.9 \mathrm{a}$ \\
\hline U. atrum $2 \mathrm{x}$ & nd & nd & $17 \mathrm{~b}$ & $0.3 \mathrm{~b}$ \\
\hline \multicolumn{5}{|l|}{ Greenhouse 2; cv. Super Serie u } \\
\hline Untreated & $830 \mathrm{a}$ & $24 \mathrm{a}$ & $46 \mathrm{a}$ & $1.4 \mathrm{a}$ \\
\hline Tween-water & $851 \mathrm{a}$ & $29 \mathrm{a}$ & $51 \mathrm{a}$ & $1.9 \mathrm{a}$ \\
\hline $\begin{array}{l}\text { Carbendazim/ dithiofencarb, } \\
\text { iprodione, iprodione }\end{array}$ & $381 \mathrm{bc}$ & $7 \mathrm{bc}$ & $19 \mathrm{bc}$ & $0.4 \mathrm{bc}$ \\
\hline U. atrum $2 \mathrm{x}$ & $643 \mathrm{ab}$ & $18 \mathrm{ab}$ & $34 \mathrm{ab}$ & $1.1 \mathrm{ab}$ \\
\hline U. atrum $4 \mathrm{x}$ & $175 \mathrm{c}$ & $6 \mathrm{c}$ & $11 \mathrm{c}$ & $0.3 \mathrm{c}$ \\
\hline \multicolumn{5}{|l|}{ Greenhouse 3; cv. Pastel ${ }^{v}$} \\
\hline Untreated & 9,424 a & $279 \mathrm{a}$ & $87 \mathrm{a}$ & $5.5 \mathrm{ab}$ \\
\hline Tween-water & $9,290 \mathrm{a}$ & $295 \mathrm{a}$ & $93 \mathrm{a}$ & $6.7 \mathrm{a}$ \\
\hline Iprodione & $10,001 \mathrm{a}$ & $330 \mathrm{a}$ & $96 \mathrm{a}$ & $7.4 \mathrm{a}$ \\
\hline U. atrum $2 \mathrm{x}$ & $8,032 \mathrm{~b}$ & $209 \mathrm{~b}$ & $89 \mathrm{a}$ & $4.4 \mathrm{bc}$ \\
\hline U. atrum $5 \mathrm{x}$ & $7,365 \mathrm{~b}$ & $164 \mathrm{~b}$ & $69 \mathrm{~b}$ & $3.2 \mathrm{c}$ \\
\hline \multicolumn{5}{|l|}{ Greenhouse 4; cv. Angliaw } \\
\hline Untreated & $3,424 \mathrm{a}$ & $64 \mathrm{a}$ & $52 \mathrm{a}$ & $2.0 \mathrm{a}$ \\
\hline Tween-water & $2,974 \mathrm{a}$ & $64 \mathrm{a}$ & $43 \mathrm{ab}$ & $1.5 \mathrm{ab}$ \\
\hline U. atrum $2 \mathrm{x}$ & $1,767 \mathrm{~b}$ & $32 \mathrm{~b}$ & $29 \mathrm{bc}$ & $0.7 \mathrm{~b}$ \\
\hline U. atrum $4 \mathrm{x}$ & $1,518 \mathrm{~b}$ & $27 \mathrm{~b}$ & $17 \mathrm{c}$ & $0.4 \mathrm{~b}$ \\
\hline \multicolumn{5}{|l|}{ Greenhouse 4; cv. Miracle ${ }^{\mathrm{x}}$} \\
\hline Untreated & $1,954 \mathrm{a}$ & $42 \mathrm{a}$ & $70 \mathrm{a}$ & $2.3 \mathrm{a}$ \\
\hline Tween-water & $1,837 \mathrm{a}$ & $41 \mathrm{a}$ & $71 \mathrm{a}$ & $2.1 \mathrm{a}$ \\
\hline U. atrum $2 \mathrm{x}$ & $409 \mathrm{~b}$ & $7 \mathrm{~b}$ & $21 \mathrm{~b}$ & $0.4 \mathrm{~b}$ \\
\hline U. atrum $3 \mathrm{x}$ & $882 \mathrm{~b}$ & $18 \mathrm{~b}$ & $26 \mathrm{~b}$ & $0.6 \mathrm{~b}$ \\
\hline \multicolumn{5}{|l|}{ Greenhouse 5; cv. Marvely ${ }^{\mathrm{y}}$} \\
\hline Untreated & $3,011 \mathrm{a}$ & $92 \mathrm{a}$ & $76 \mathrm{ab}$ & $3.6 \mathrm{a}$ \\
\hline Tween-water & $2,841 \mathrm{a}$ & $89 \mathrm{a}$ & $78 \mathrm{a}$ & $3.2 \mathrm{a}$ \\
\hline Tolylfluanid & $2,555 \mathrm{a}$ & $69 a b$ & $67 a b$ & $2.6 \mathrm{a}$ \\
\hline U. atrum $2 \mathrm{x}$ & $1,885 \mathrm{~b}$ & $49 \mathrm{~b}$ & $65 \mathrm{ab}$ & $2.4 \mathrm{a}$ \\
\hline U. atrum $3 \mathrm{x}$ & $1,802 \mathrm{~b}$ & $44 \mathrm{~b}$ & $63 \mathrm{~b}$ & $2.2 \mathrm{a}$ \\
\hline \multicolumn{5}{|l|}{ Greenhouse 5; cv. Sierra ${ }^{z}$} \\
\hline Untreated & $2,409 \mathrm{~b}$ & $54 \mathrm{~b}$ & $78 \mathrm{a}$ & $2.7 \mathrm{a}$ \\
\hline Tween-water & $3,244 \mathrm{a}$ & $73 \mathrm{a}$ & $85 \mathrm{a}$ & $3.3 \mathrm{a}$ \\
\hline U. atrum $2 \mathrm{x}$ & $1,577 \mathrm{c}$ & $27 \mathrm{c}$ & $51 \mathrm{~b}$ & $1.2 \mathrm{~b}$ \\
\hline U. atrum $3 \mathrm{x}$ & $1,816 \mathrm{c}$ & $28 \mathrm{c}$ & $43 \mathrm{~b}$ & $0.9 \mathrm{~b}$ \\
\hline
\end{tabular}

${ }^{\circ} U$. atrum was applied as conidial suspension containing $0.01 \%$ Tween 80 with $1 \times 10^{6}$ conidia per $\mathrm{ml}$. The water control contained $0.01 \%$ Tween 80 . No data provided for three experiments in greenhouse 6 , where $U$. atrum or fungicides were not effective.

$\mathrm{p}$ Disease incidence (DI) measured as the percentage of plants with $B$. cinerea symptoms.

${ }^{q}$ Disease severity (DS) measured as the number of leaves or flower petioles per plant with $B$. cinerea symptoms.

${ }^{\mathrm{r}}$ Experiment started with 168-day-old plants, and plants were marketable at 224 days. U. atrum and Tween-water were applied at plant ages 168 and 196 days (U. atrum 2x).

${ }^{s}$ Not determined because DI and DS were assessed only three times.

${ }^{t}$ Values of the same experiment within one column with a common letter do not differ statistically $(P$ $>0.05$ ).

" Experiment started with 77-day-old plants, and plants were marketable at 189 days. U. atrum was applied at plant ages 77 and 105 days (U. atrum $2 x)$ or 77, 105, 136, and 163 days (U. atrum 4x). Tween-water was applied at ages 77, 105, 136, and 163 days. Carbendazim plus dithiofencarb (as Sumico at $1 \mathrm{~g} / \mathrm{liter}$; at $250 \mathrm{~g}$ a.i. $/ \mathrm{kg}$ and $250 \mathrm{~g}$ a.i./.kg, respectively), iprodione (as Rovral at 1 $\mathrm{ml} /$ liter; at $500 \mathrm{~g}$ a.i./liter), and iprodione were applied in rotation at ages 111, 125, and 153 days, respectively.

Experiment started with 133-day-old plants, and plants were marketable at 263 days. U. atrum was applied at plant ages 133 and 157 days $(U$. atrum $2 x)$ or 133, 157, 184, 211, and 240 days $(U$. atrum 5x). Tween-water was applied at ages 133, 157, 184, 211, and 240 days. Iprodione (as Rovral with $1 \mathrm{ml} /$ liter; at $500 \mathrm{~g}$ a.i./liter) was applied at 149 days.

${ }^{\text {w}}$ Experiment started with 126-day-old plants, and plants were marketable at 229 days. U. atrum was applied at plant ages 126 and 154 days (U. atrum 2x) or 126, 154, 182, and 208 days (U. atrum 4x). Tween-water was applied at ages $126,154,182$, and 208 days.

${ }^{x}$ Experiment started with 119-day-old plants, and plants were marketable at 196 days. U. atrum was applied at plant ages 119 and 147 days (U. atrum 2x) or 119, 147, and 175 days (U. atrum 3x). Tween-water was applied at ages 119,147 , and 175 days.

${ }^{y}$ Experiment started with 140-day-old plants, and plants were marketable at 214 days. U. atrum was applied at plant ages 140 and 167 days $(U$. atrum $2 x)$ or 140, 167, and 195 days ( $U$. atrum 3x). Tween-water was applied at ages 140, 167, and 195 days. Tolylfluanid (as Euparene M at $1 \mathrm{~g} /$ liter; at $500 \mathrm{~g}$ a.i. $/ \mathrm{kg}$ ) was applied at 147 days.

2 Experiment started with 140-day-old plants, and plants were marketable at 222 days. U. atrum was applied at plant ages 140 and 167 days ( $U$. atrum 2x) or 140, 167, and 195 days ( $U$. atrum 3x). Tween-water was applied at ages 140, 167, and 195 days.
Growing conditions. Ten experiments were carried out in six different commercial greenhouses located in western and central Netherlands. In all greenhouses, the minimum temperature during daytime was set at approximately $14^{\circ} \mathrm{C}$ and during nighttime at approximately $16^{\circ} \mathrm{C}$, as is usual in the Dutch cyclamen production system.

The growing systems in the different greenhouses differed considerably in the arrangement of plants, irrigation system, heating system, and type of material used for pots (Table 2). In all greenhouses, plants were irrigated two to three times per week. During the experiments, plant spacing was increased to avoid touching of leaves of different plants, except in greenhouse 6 , where spacing was not increased during the last 50 days of the experiments. Under these conditions, leaves of neighboring plants touched each other and formed a dense canopy layer. Plants with the first flowers open were considered marketable, except for those in greenhouse 3 , where the first flowers were removed and plants were left in the greenhouse for an additional 30 days.

Treatments. In most experiments, five treatments were arranged in a randomized complete block design, with each treatment replicated four times. Each replication of a treatment consisted of 24 plants arranged in three or four rows. Between treatments, one untreated row of plants served as a buffer. The treatments consisted of spraying the plants with: (i) tap water containing $0.01 \%$ (vol/vol) Tween 80; (ii) the fungicide program as applied by the grower in his commercial growing system (as described in Table 1); (iii) inoculation with conidial suspensions of $U$. atrum twice (at the beginning of the experiment and approximately 28 days later); (iv) inoculation with conidial suspensions of $U$. atrum at intervals of approximately 28 days from the beginning of the experiment until approximately 28 days before plants were marketable; and (v) untreated plants that served as controls. No fungicide treatments were made in greenhouses 1 and 4 and in one of the two experiments in greenhouse 5 . In these cases, data of untreated plants that had been planned for fungicide treatments are not presented. In the experiment in greenhouse 1, the two different spraying strategies for the antagonist did not differ since the plants were marketable within 8 weeks after the beginning of the experiment. In this case, data of the $U$. atrum application at 4-week intervals are not presented.

Fungicides applied by different growers were Euparene M (1 g/liter, tolylfluanid at $500 \mathrm{~g}$ a.i./kg; Bayer AG, Leverkusen, Germany); Daconil M (1 g/liter, chlorothalonil at $250 \mathrm{~g}$ a.i. $/ \mathrm{kg}$ and maneb at $500 \mathrm{~g}$ a.i./kg; AgrEvo, Frankfurt, Germany); Rovral (1 $\mathrm{ml} /$ liter, iprodione at $500 \mathrm{~g}$ a.i./liter; Rhone-Poulenc Agrochemie, 
Lyon, France); or Sumico (1 g/liter, carbendazim at $250 \mathrm{~g}$ a.i. $/ \mathrm{kg}$ and diethofencarb at $250 \mathrm{~g}$ a.i./kg; AgrEvo).

Application dates for experiments in greenhouses 1 to 5 are given in Table 1. In greenhouse 6 , three experiments were carried out, each with a different cultivar. Plants were 126 days old at the beginning of the experiment and were marketable within 254 days. $U$. atrum was applied at plant ages of 126 and 150 days or at 126 , 150, 177, 206, and 233 days. Tween-water was applied at plant ages of 126, 150, 177, 206, and 233 days. Chlorothalonil and mancozeb (as Daconil M at $1 \mathrm{~g} /$ liter) were applied at plant ages of 143 and 168 days, and iprodione (as Rovral at $1 \mathrm{~g} /$ liter) was applied at 190 and 240 days.

Application technique. Water and antagonist suspensions were applied with a propane-operated sprayer (AZO, Ede, the Netherlands) at $250 \mathrm{kPa}$. Fungicides were applied by growers using motor-operated sprayers. During spraying, frames with polyethylene were placed around each treatment to prevent drift to neighboring plants. The canopies of individual plants were sprayed until runoff. Later, when the canopy of plants became very dense, the spray nozzle was also placed inside the canopy to reach all surfaces of leaves, petioles, and the tuber with the suspension. Growers also use this technique for fungicide applications.

Assessments. In each experiment, disease was assessed on days when $U$. atrum was applied, and a final assessment was made approximately 28 days after the last treatment, when plants were marketable. The numbers of leaves or flower petioles with sporulation of $B$. cinerea were recorded for each plant. From these data, the percentage of plants with disease symptoms of B. cinerea (disease incidence, DI) and the number of diseased leaves and flower petioles per plant (disease severity, DS) were calculated.

Survival of $U$. atrum conidia on topirrigated green leaves of cyclamen plants and competitive colonization of senesced leaves by $B$. cinerea and $\boldsymbol{U}$. atrum. Fifty 20-week-old potted cyclamen plants (cv. Super Serie) were grown in a greenhouse at $20 \pm 3^{\circ} \mathrm{C}$ and $65 \pm 20 \%$ relative humidity $(\mathrm{RH})$. Pots were placed on a table on capillary mats. Petioles of fully developed leaves were labeled with colored, plastic- coated iron rings. Water was applied by top-irrigation using a sprinkler. Plants were irrigated at approximately 1 liter $/ \mathrm{m}^{2}$ at a intervals of 2 to 3 days. Experimental plots consisted of five plants, each sprayed with a conidial suspension of $U$. atrum (prepared as described above) or tap water containing $0.01 \%$ Tween 80 . The experiment was arranged in a randomized complete block design, with each treatment replicated five times and the experiment repeated once.

Three labeled leaves per replicate were sampled at day $0,2,4,7,10,14,21,28$, 42,56 , and 70 after spraying. Conidial density and conidial germination of $U$. atrum directly after sampling and after additional incubation in a moist chamber at $24^{\circ} \mathrm{C}$ for $8 \mathrm{~h}$ were determined on one leaf per replicate at each of the sampling dates as described by Köhl et al. (7). The other two leaves sampled per replicate at each of the sampling dates were placed in open petri dishes on two dry filter papers. Petri dishes were arranged in blocks in the greenhouse as previously described for plants but were not irrigated. Forty-two days after sampling, when all these leaves had senesced, $0.75 \mathrm{ml}$ of sterile tap water was added to the filter paper in each petri dish, and the closed petri dishes were transferred to an incubator. Leaves were incubated for 14 days in the dark at $18^{\circ} \mathrm{C}$. Thereafter, the coverage of the leaf area with conidiophores of $B$. cinerea was estimated as described by Köhl et al. (7).

Statistics. Linear logistic regression was employed to explain the percentage of DI in response to the classifying variable: replicate and treatment. Log-linear regression models with the same classifying variables were fitted to the data on the number of diseased leaves and flower petioles per plant (DS). Overall effects of replicate and treatment were assessed using $F$ tests for the ratio of the mean deviance for the particular effect and the mean residual deviance. In cases where $F$ tests were significant $(P<0.05)$, treatment means on the logit or log-scale were separated by twosided $t$ tests $(P<0.05)$, corresponding to least significant difference (LSD) tests for normally distributed data.

Area under disease progress curves (AUDPC) for DI and DS were analyzed by ANOVA. ANOVA was also employed on angular-transformed data on sporulation of
$B$. cinerea on dead leaves of the experiment on the survival of $U$. atrum inoculum. Significant $F$ tests $(P<0.05)$ were followed by two-sided LSD tests $(P<0.05)$ for testing pairwise differences between treatment means.

All analyses were performed with the Genstat 5 program (Numeral Algorithms Group Inc., Oxford, UK).

\section{RESULTS}

Disease control. Gray mold occurred in all 10 experiments. DI at marketing ranged between 41 and $87 \%$ in the untreated controls for experiments carried out in greenhouses 1 to 5 (Table 1), and was above $90 \%$ in the three experiments carried out in greenhouse 6 (data not shown). The experiments were not designed to compare the effect of different growing systems or cultivars on $B$. cinerea development; therefore, no conclusions can be drawn about the reasons for such a variable level of disease between experiments.

When $U$. atrum was applied at 4-week intervals, DI at marketing was significantly lower than in the water controls in seven of the 10 experiments. In the three experiments carried out in greenhouse 6 , five $U$. atrum applications at 4-week intervals showed no effect. DS at marketing ranged between 0.8 and 11.0 in the untreated controls in the 10 experiments, with exceptionally high values above 7.0 in greenhouse 6. A significant reduction in DS after four weekly applications of $U$. atrum was found for five experiments. Again, there was no effect by U. atrum in greenhouse 6. The application of $U$. atrum twice at the beginning of the experiment was less effective on DI and DS at marketing when compared with applications at 4-week intervals when crops were marketed more than 60 days after the second treatment (greenhouses 2, 3, 4, and 6). Significant effects of $U$. atrum applications at 4-week intervals were found on the disease progression as expressed by AUDPC for both DI and DS in five of the nine experiments where AUDPC could be determined. The significant effects of only two applications of $U$. atrum at the beginning of the experiments were found more often on disease development (AUDPC) than on DI and DS at marketing.

Fungicide applications reduced DI and DS at marketing and AUDPCs signifi-

Table 2. Growing systems in greenhouses 1 to 6

\begin{tabular}{|c|c|c|c|c|}
\hline Greenhouse no. & Pot & Plant arrangement & Irrigation & Heating \\
\hline 1 & Clay & Concrete floor & Ebb and flow & Additional tubes $30 \mathrm{~cm}$ above plants \\
\hline 2 & Plastic & Tables & Capillary matting & \\
\hline 3 & Plastic & $\begin{array}{l}\text { Tables; from plant age } 150 \text { days on } \\
\text { gutters }\end{array}$ & $\begin{array}{l}\text { Top-irrigation; from plant age } 150 \\
\text { days intermittent flow irrigation }\end{array}$ & \\
\hline 4 & Plastic & $\begin{array}{l}\text { Ground on polyethylene foil; from } \\
\text { plant age } 190 \text { days on gutters }\end{array}$ & $\begin{array}{l}\text { Top-irrigation; from plant age } 190 \\
\text { days intermittent flow irrigation }\end{array}$ & Additional tubes $30 \mathrm{~cm}$ above plants \\
\hline 5 & Plastic & Tables & Capillary matting plus top-irrigation & \\
\hline $6^{\mathrm{z}}$ & Clay & Tables & Capillary matting plus top-irrigation & \\
\hline
\end{tabular}

${ }^{\mathrm{z}}$ Data of experiments not presented in Table 1. 


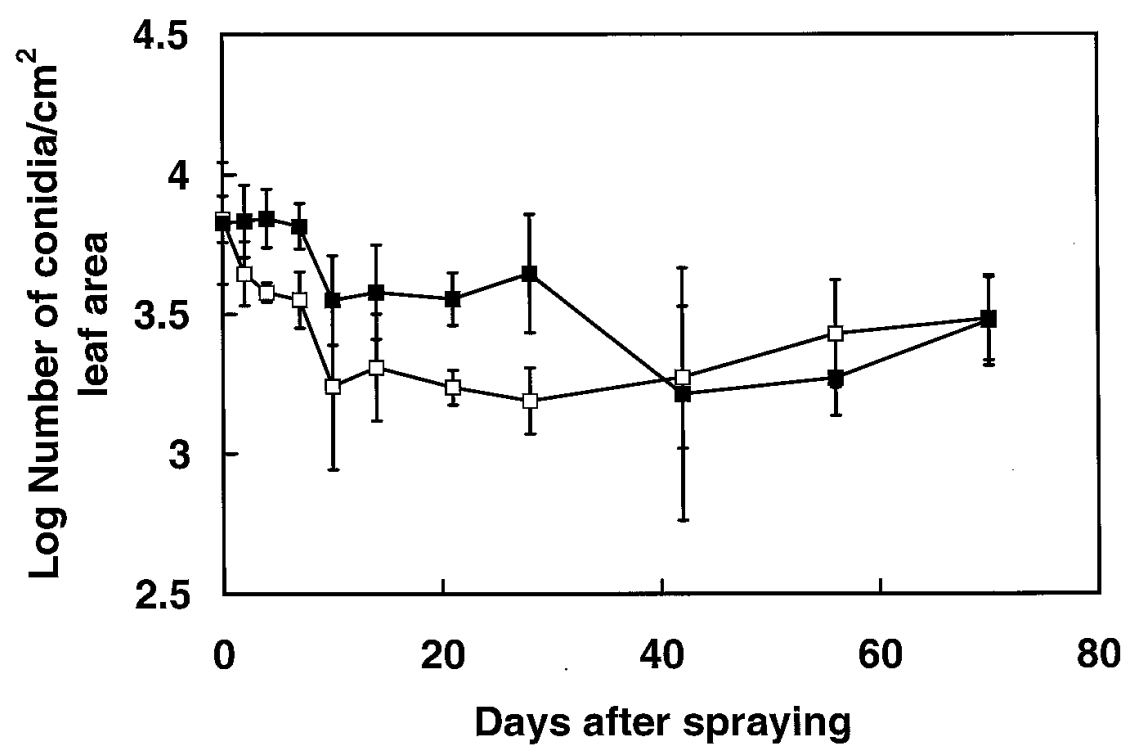

Fig. 1. Density of conidia of Ulocladium atrum on green leaves of cyclamen plants (cv. Super Serie) under greenhouse conditions with top-irrigation three times per week ( $\square=$ experiment 1 ; $\mathbf{\square}=$ experiment 2). Leaves were sprayed with a conidial suspension $\left(1 \times 10^{6}\right.$ conidia per $\left.\mathrm{ml}\right)$ at day 0 . Means \pm standard errors of the mean of five leaves (replicates) per assessment date.

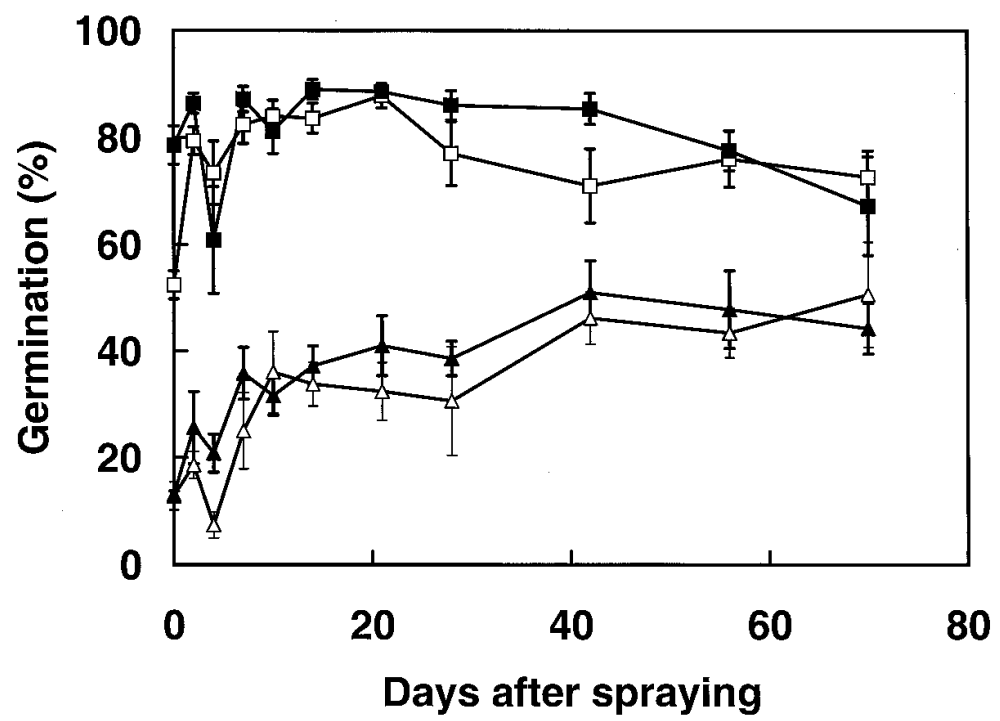

Fig. 2. Germination of conidia of Ulocladium atrum on green leaves of cyclamen plants (cv. Super Serie) under greenhouse conditions with top-irrigation three times per week. Leaves were sprayed with a conidial suspension $\left(1 \times 10^{6}\right.$ conidia per $\left.\mathrm{ml}\right)$ at day 0 . Germination was assessed directly after sampling ( $\Delta=$ experiment $1 ; \boldsymbol{\Delta}=$ experiment 2$)$ or after incubation in moist chamber at $24^{\circ} \mathrm{C}$ for $8 \mathrm{~h}$ ( $\square=$ experiment $1 ; \boldsymbol{\square}=$ experiment 2 ). Means \pm standard errors of the mean for 100 conidia on each of five leaves (replicates) per assessment date.

cantly in greenhouse 2 , but not in greenhouses 3,5 , and 6 . In no case did fungicide applications give better control than $U$. atrum applied at 4-week intervals.

Survival of $U$. atrum conidia on cyclamen leaves. Densities of $U$. atrum conidia on green cyclamen leaves were 6,900 and 6,700 conidia per $\mathrm{cm}^{2}$ at the beginning of experiments 1 and 2, respectively. Densities decreased to 1,700 and 3,500 conidia per $\mathrm{cm}^{2}$ during the first 10 days of the two experiments and thereafter remained relatively stable (Fig. 1; data presented as Log10 numbers). At the end of both experiments, approximately 3,000
Competitive colonization of dead leaves by $B$. cinerea and $U$. atrum. In both experiments, for all sampling dates, dead leaves were naturally contaminated in the greenhouse with $B$. cinerea, resulting in a leaf coverage with sporulating $B$. cinerea after incubation in a moist chamber ranging from 17.5 to $59.5 \%$ on leaves not treated with $U$. atrum (Fig. 3A). Significantly less $(P<0.05) B$. cinerea sporulation was found on $U$. atrum-treated leaves for all sampling dates, except for leaves sampled 70 days after $U$. atrum application in experiment 1 . The efficacy of the $U$. atrum treatment was highest on leaves sampled at the beginning of the experiment, with 100 and $97 \%$ for experiments 1 and 2, respectively (Fig. 3B). Thereafter, efficacy ranged between 51 and $96 \%$, except for the last sampling date of experiment 1 , where efficacy was only $29 \%$.

\section{DISCUSSION}

In an earlier study, $U$. atrum showed significant potential to control $B$. cinerea in commercially grown cyclamen (7). These results were all obtained in the same greenhouse, where no top-irrigation was applied. Results presented in our study confirmed these findings but add essential novel information on the potential of the antagonist in a variety of cyclamen growing systems.

At the beginning of the study, it was hypothesized that $U$. atrum may be less effective in situations where top-irrigation is applied, since conidia may be washed off. Furthermore, top-irrigation, especially in combination with capillary matting, results in a higher relative humidity within the canopy and thus may favor $B$. cinerea (4). On the other hand, during periods with low relative humidity in the greenhouse, topirrigation will result in leaf wetness periods of only a few hours, allowing conidia of $U$. atrum to germinate. Under these alternating conditions, such germinated conidia may become exhausted after several wetdry cycles because of insufficient nutrient supply and thus be lost.

The results of the experiments in the different commercial greenhouses show that $U$. atrum controls $B$. cinerea when sprayed at 4-week intervals, except when the disease pressure of $B$. cinerea was extremely high, as in greenhouse 6 . Under such conditions, even fungicide applications did not control the disease.

No indications were found that top-irrigation, as applied in greenhouses $3,4,5$, and 6 , affected the efficacy of $U$. atrum applications. This finding is in line with the results obtained in experiments where the survival of $U$. atrum conidia in the cyclamen canopy was monitored in a growing system with top-irrigation. Under these conditions, a significant part of the conidia had the ability to attach to green leaves of cyclamen and to survive. An- 

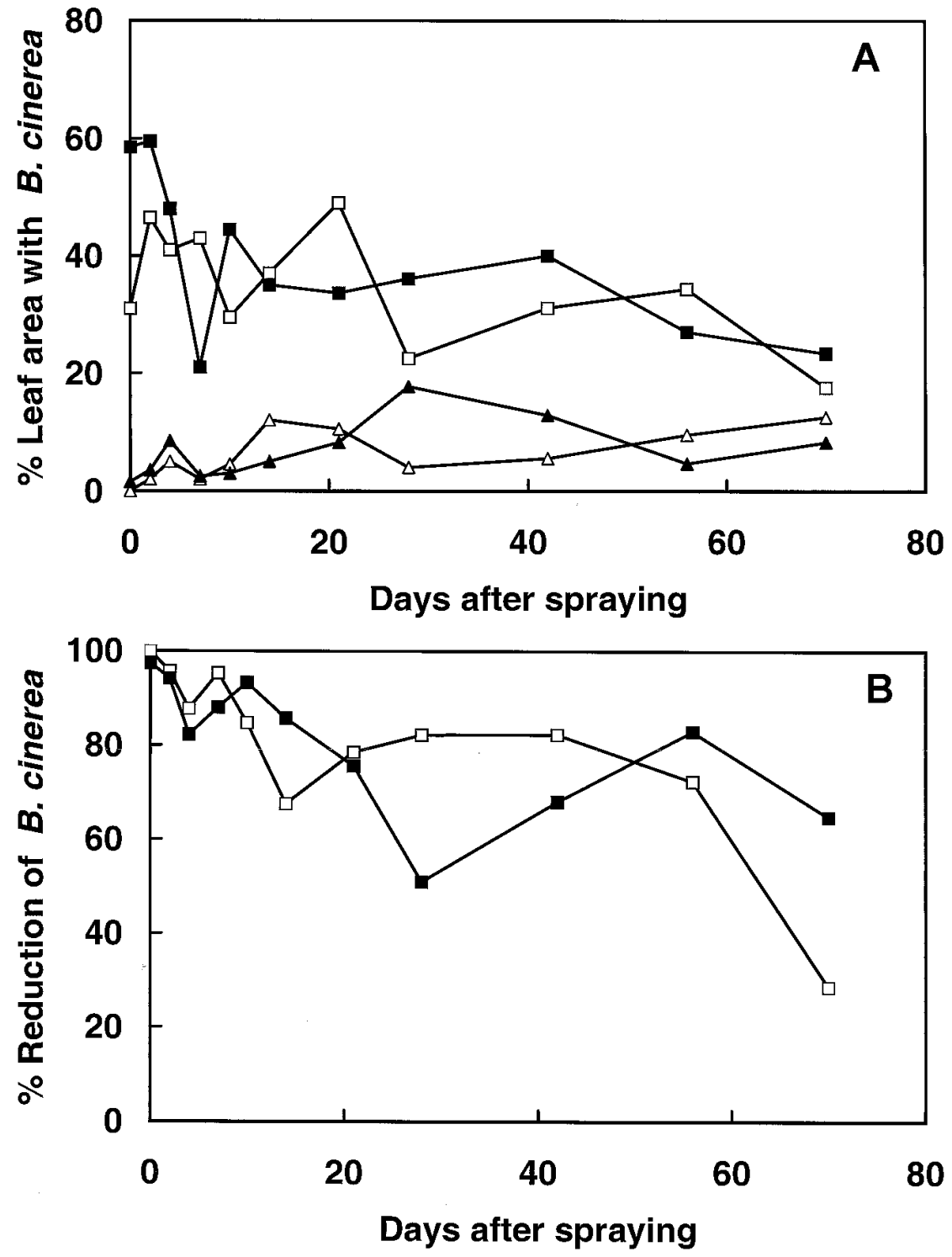

Fig. 3. Effect of an Ulocladium atrum treatment on sporulation of Botrytis cinerea on dead cyclamen leaves. Green leaves of cyclamen plants were sprayed with conidial suspension of $U$. atrum $\left(1 \times 10^{6}\right.$ conidia per $\mathrm{ml}$ ) at day 0 and kept under greenhouse conditions with top-irrigation three times per week. Leaves were detached from plants at the indicated sampling date, allowed to senesce during 42 days in the greenhouse (not irrigated) and exposed to natural deposition of $B$. cinerea conidia, and subsequently incubated in a moist chamber $\left(14\right.$ days, $\left.18^{\circ} \mathrm{C}\right)$. (A) Percent leaf area with $B$. cinerea sporulation on dead cyclamen leaves treated with $U$. atrum $(\Delta=$ experiment $1 ; \boldsymbol{\Delta}=$ experiment 2$)$ or with Tween-water $(\square=$ experiment $1 ; \boldsymbol{\square}=$ experiment 2$)$. The two treatments differed significantly $(P<0.05)$ at all assessment dates according to LSD, except for the last sampling date for experiment 1. (B) Efficacy of $U$. atrum treatment in B. cinerea control $(\square=$ experiment $1 ; \mathbf{\square}=$ experiment 2$)$.

tagonistic activity of $U$. atrum propagules against $B$. cinerea was found in necrotic tissue when conidia had been sprayed onto green leaves 10 weeks before necrosis was induced by removing leaves from plants. Given that leaves were allowed to senesce slowly under dry conditions during the 6 weeks after removal from the plant, $U$. atrum retained its antagonistic potential for a total of 16 weeks after application. These findings on the persistence of $U$. atrum propagules confirm results obtained in of $U$. atrum with fungicides is needed. The combined application of the antagonist with compatible fungicides may further improve disease control. With such an integrated approach, disease control may also be possible in situations with a high disease pressure (as in greenhouse 6) or when $B$. cinerea already is established in the canopy before the first applications are carried out (as in greenhouse 3).

\section{ACKNOWLEDGMENTS}

We thank the Dutch Study Club of Cyclamen Growers for supporting experiments in greenhouses of several members. We gratefully acknowledge N. J. Fokkema for stimulating discussions, W. M. L. Molhoek for technical assistance, and P. F. G. Vereijken and E. van Remortel for statistically analyzing the data.

\section{LITERATURE CITED}

1. Bollen, G. J., and Scholten, G. 1971. Acquired resistance to benomyl and some other fungicides in a strain of Botrytis cinerea in cyclamen. Neth. J. Plant Pathol. 77:83-90.

2. Elad, Y. 1996. Mechanisms involved in the biological control of Botrytis cinerea incited diseases. Eur. J. Plant Pathol. 102:719-732.

3. Elmer, P. A. G., and Köhl, J. 1998. The survival and saprophytic competitive ability of the Botrytis spp. antagonist Ulocladium atrum in lily canopies. Eur. J. Plant Pathol. 104:435-447.

4. Grantzau, E., and ter Hell, B. 1993. Botrytis bei Cyclamen. Einfluss von Bewässerungssystem, Düngung oder Substrat. Gartenbau Gartenwirtschaft 93:542-543.

5. Gullino, M. L. 1992. Chemical control of Botrytis spp. Pages 217-222 in: Recent Advances in Botrytis Research. K. Verhoeff, N. E. Malathrakis, and B. Williamson, eds. Pudoc Scientific Publishers, Wageningen, Netherlands.

6. Henseler, K. 1981. Fungizide beeinträchtigen den Ertrag. Möglichkeiten der BotrytisBekämpfung bei Schnittcyclamen. Gartenbau Gartenwirtschaft 81:382.

7. Köhl, J., Gerlagh, M., De Haas, B. H., and Krijger, M. C. 1998. Biological control of Botrytis cinerea in cyclamen with Ulocladium atrum and Gliocladium roseum under commercial growing conditions. Phytopathology 88:568-575.

8. Köhl, J., Molhoek, W. M. L., van der Plas, C. H., and Fokkema, N. J. 1995. Suppression of sporulation of Botrytis spp. as a valid biocontrol strategy. Eur. J. Plant Pathol. 101:251-259.

9. Köhl, J., Molhoek W. M. L., van der Plas, C. H., and Fokkema, N. J. 1995. Effect of Ulocladium atrum and other antagonists on sporulation of Botrytis cinerea on dead lily leaves exposed to field conditions. Phytopathology 85:393-401.

10. Köhl, J., van der Plas, C. H., Molhoek, W. M. L., and Fokkema, N. J. 1995. Effect of interrupted leaf wetness periods on suppression of sporulation of Botrytis allii and B. cinerea by antagonists on dead onion leaves. Eur. J. Plant Pathol. 101:627-637.

11. Pappas, A. C. 1982. Inadequate control of grey mould on cyclamen by dicarboximide fungicides in Greece. Z. PflanzenKrankh. PflanzenSchutz. 89:52-58.

12. Schlösser, E. 1978. Entwicklungsstadien von Alpenveilchenblättern (Cyclamen persicum) Besiedlung durch Botrytis cinerea. Z. PflanzenKrankh. PflanzenSchutz. 85:179-185. 